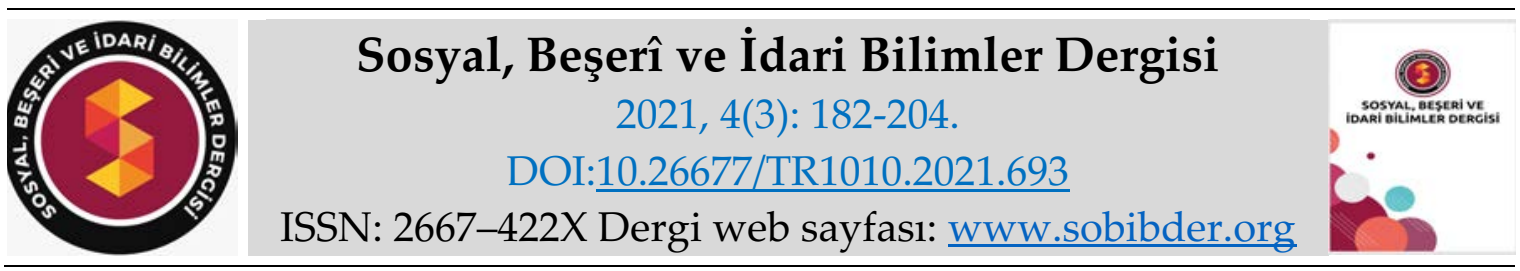

ARAȘTIRMA MAKALESI

\title{
Kamu Özel Sektördeki Yenilikçilik Davranışı ve Girişimcilik Niyeti İlişkisinde Aile Geçmişinin Etkilerinin Çok Boyutlu Analizi: Bir Alan Araştırması
}

Salih SERBEST, Doktora Öğrencisi, Ankara Hacı Bayram Veli Üniversitesi, Lisansüstü Eğitim Enstitüsü, Ankara, e-posta: salih.serbest@hbv.edu.tr ORCID: https://orcid.org/0000-0003-1137-0763

Doç. Dr. Aykut GÖKSEL, Ankara Hacı Bayram Veli Üniversitesi, İktisadi ve İdari Bilimler Fakültesi, Ankara, e-posta: aykut.goksel@hbv.edu.tr

ORCID: https://orcid.org/0000-0003-2780-8117

Öz

$\mathrm{Bu}$ araştırmanın temel amacı; kamu ve özel sektörde çalışanların göstermiş oldukları yenilikçi davranışlar ile girişimcilik niyeti tutumlarının demografik özellikler açısından incelenmesinde aile geçmişinin etkilerini araştırmaktır. Bu kapsamda, araştırmada girişimcilik niyetine etkisinin olduğu düşünülen girişimci kişilik özelliklerinden olan yenilikçi davranış faktörü demografik özelliklerle birlikte ele alınıp incelenirken aynı zamanda aile geçmişinin etkileri de dikkate alınarak analizler yapılmıştır. Araştırmanın problem cümleleri şu şekilde oluşturulmuştur: "Kamu ve özel sektörde çalışanların girişimcilik niyeti tutumunda kurumda çalışanların göstermiş oldukları yenilikçi davranışlar nelerdir?", "Aile geçmişinin kamu ve özel sektörde çalışanların göstermiş oldukları yenilikçi davranışlar ile girişimcilik niyeti tutumları üzerindeki etkileri nelerdir?". Araştırmanın amacına uygun verileri toplamak için nicel araştırma yöntemlerinden anket tekniği kullanılmıştır. Oluşturulan veri toplama aracı 3 bölümden oluşmaktadır. Birinci bölümde demografik özellikler, ikinci bölümde girişimcilik niyeti anketi ve üçüncü bölümde yenilikçi davranış anketi yer almaktadır. Birinci bölümde kamu ve özel sektör çalışanlarının demografik bilgilerini belirlemek amacıyla 16 soru yer almaktadır. İkinci ve üçüncü bölümlerde beşli Likert olarak hazırlanmış olan anketler toplam 16 maddeden oluşmaktadır. Araştırma kapsamında 158 kamu sektörü ve 88 özel sektörde olmak üzere toplam 246 kişiye anket uygulanmıştır.

Anahtar Kelimeler: Girişimci, Girişimcilik, Girişimcilik Niyeti, Yenilikçilik, Yenilikçi Davranış.

Makale Gönderme Tarihi: 03.11.2020

Makale Kabul Tarihi: 05.03.2021

\section{Önerilen Atıf:}

Serbest, S. ve Göksel, A. (2021). Kamu Özel Sektördeki Yenilikçilik Davranışı ve Girişimcilik Niyeti İlişkisinde Aile Geçmişinin Etkilerinin Çok Boyutlu Analizi: Bir Alan Araştırması, Sosyal, Beşeri ve İdari Bilimler Dergisi, 4(3): 182-204.

(c) 2021 Sosyal, Beşerî ve İdari Bilimler Dergisi. 


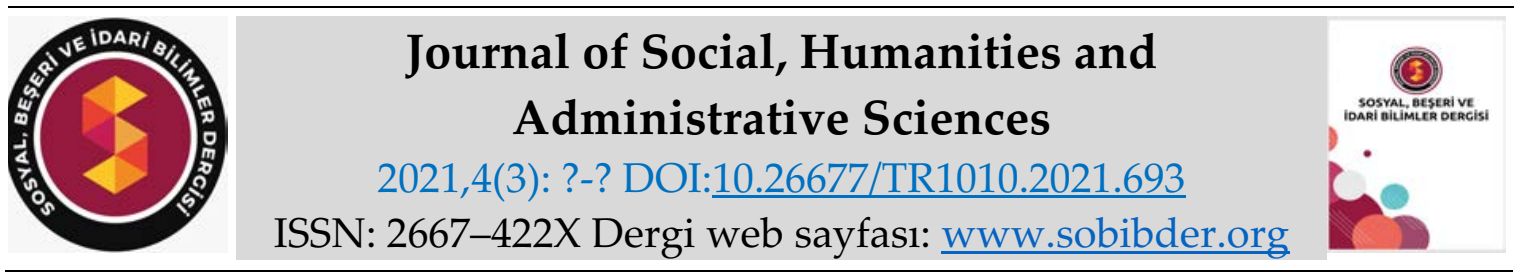

RESEARCH PAPER

\title{
Multidimensional Analysis of The Effects of Family Background on The Relationship Between Innovation Behaviour and Entrepreneurial Intention in The Public Private Sector: A Field Research
}

\author{
Salih SERBEST, Ph.D. Student, Ankara Hacı Bayram Veli University, Graduate Education \\ Institute, Ankara, e-mail: salih.serbest@hbv.edu.tr \\ ORCID: https://orcid.org/0000-0003-1137-0763
}

Associate Prof. Dr. Aykut GÖKSEL, Ankara Hacı Bayram Veli University, Faculty of Economics and Administrative Sciences, Ankara, e-mail: aykut.goksel@hbv.edu.tr

ORCID: https://orcid.org/0000-0003-2780-8117

\begin{abstract}
The main purpose of this research; to investigate the effects of family background in examining the innovative behaviours and entrepreneurial intentions of the public and private sector employees in terms of demographic characteristics. In this context, while analyzing the innovative behavioural factor, which is an entrepreneurial personality trait, which is thought to have an impact on entrepreneurial intention in the research, was analyzed by taking into account the effects of the family background. The problem statements of the research were formed as follows: "What are the innovative behaviours of the employees working in the institution in the attitude of entrepreneurial intention of the employees in the public and private sectors?", "What are the effects of family background on innovative behaviours of the public and private sector employees and their entrepreneurial intentions?". Questionnaire technique, one of the quantitative research methods, was used to collect data suitable for the purpose of the research. The data collection tool created consists of 3 parts. In the first part, demographic characteristics, in the second part, entrepreneurial intentions survey and in the third part, innovative behaviour survey. In the first part, there are 16 questions to determine the demographic information of public and private sector employees. The questionnaires which were prepared as five-point Likert in the second and third sections consist of a total of 16 items. Within the scope of the research, a total of 246 people were surveyed, 158 in the public and 88 private sectors.
\end{abstract}

Keywords: Entrepreneur, Entrepreneurship, Entrepreneurial Intention, Innovation, Innovative Behaviour. Received: 03.11.2020

Accepted: 05.03.2021

\section{Suggested Citation:}

Serbest, S. and Göksel, A. (2021). Multidimensional Analysis of The Effects of Family Background on The Relationship Between Innovation Behaviour and Entrepreneurial Intention in The Public Private Sector: A Field Research, Journal of Social, Humanities and Administrative Sciences, 4(3): 182-204.

(C) 2021 Sosyal, Beşerî ve İdari Bilimler Dergisi. 


\section{Gíriş}

Girişimcilik, zaman ve çaba harcayarak, finansal, psikolojik ve sosyal riskleri göz önünde bulundurarak ve maddi ve bireysel kazanımları hedefleyerek yeni ve farklı değerli şeyler yaratma süreci olarak tanımlanmaktadır (Hisrich, 1986; Shane ve Venkataraman, 2000). Yönetim Akademisine göre girişimcilik "yeni işletmelerin, küçük işletmelerin ve aile işletmelerinin oluşturulması ve yönetimi"dir (Coulter, 2003:4). Girişimcilik, mevcut kaynaklara bakılmaksızın bir fırsat arayışıdır ve girişimciler kendilerini bu fırsatların takipçileri olarak algılarlar (Stevenson vd., 1989). Girişimcilik sadece bireysel bir eylem olmayıp, aynı zamanda grupların ve kurumların eylemlerini de kapsamaktadır (Shapero, 1982). Girişimcilik planlı hareketleri içermekte ve bireylerin çevresini etkilemeyi amaçlamaktadır (Bird, 1988).

Birçok araştırmacı, girişimci davranışın bireyin iç kontrol odağının yüksek seviyesine (Shapero, 1975; Brockhaus, 1982; Perry, 1990; Göksel ve Aydıntan, 2011), proaktif özelliklere (Bateman ve Crant, 1993; White, 1959; Langer, 1983) ve başarılı olma ihtiyacına bağlı olduğunu düşünmektedir (McClelland, 1961; Liles, 1974). Bunların yanı sıra eğitim, cinsiyet ve aile mesleğinin girişimci davranışlar üzerindeki etkileri de birçok bilim adamı tarafından incelenmiştir (Gomolka, 1977; Thorne ve Ball, 1981; Collins ve Moore, 1970).

$\mathrm{Bu}$ çalışma, davranış̧̧ı kuramda bütünsel bir araştırma modeli olarak girişimcilik niyeti üzerindeki etkileri açısından, aile meslekleri ve demografik özellikler arasındaki ilişkilere bakmaktadır.

Türkiye' deki girişimciler aracılığıyla ekonomik kalkınmanın sağlanması ve girişimciliğin tarihsel gelişimi bu alandaki araştırmaların önemini artırmaktadır. Göçebe yaşam tarzı ve Türk ulusal tarihinde sık sık hareket etme göz önüne alındığında, risk alma, adaptasyon ve girişimcilik özellikleri kolayca talep edilebilmektedir (Göksel ve Aydıntan, 2011:35).

Ancak, Osmanlı dönemindeki ticari faaliyetler göz ardı edildiğinde, bu alan Türkler için sınırlandırılmış ve girişimcilik kültürünün öğrenilmesi ertelenmiştir. Bu çerçevede, Türkiye'den yapılan araştırmaların, halen uluslararası literatürde tanınmayı amaçlayan girişimcilik üzerine çalışmalara katkıda bulunması gerektiğine inanılmaktadır (Göksel ve Aydıntan, 2011:36).

Girişimcilikle ilgili bir diğer kavram olan girişimcilik niyeti ise, bireyin kendi işini kurmak için girişimci gayretler gösterme yönündeki eylemlere bağlllı̆̆ı olarak tanımlanmaktadır (Şeşen ve Basım, 2012).

Bilgi çağının yarattığı etkilere oldukça duyarlı olan günümüz dünyasında bilimsel ve teknolojik gelişmeler, değişen çevre şartları, giderek artan rekabet baskısı, beklentileri farklılaşan sosyal ve politik yapı gibi etkenler örgütlerin yenilik (inovasyon) konusunda ısrarlı olmalarını gerektirmektedir. Bu anlamda inovasyon, örgütlerin diğerlerinden pozitif olarak ayrışmasını ve rekabet avantajını elde etmesini sağlamaktadır (Çimen ve Yücel, 2017:366). Örgütlerin yenilikçi bir yapıya sahip olması, çalışanlarının ilk başta yenilikçi davranışlar gösterip göstermediklerine bağlıdır. Çünkü örgütün değişmesi ve gelişmesi için örgütteki birimlerin ikna edilmesi ve bu yönde çaba göstermesi gerekir (Lewin, 1951).

\section{KAVRAMSAL ÇERÇEVE}

\section{Girişimci, Girişimcilik ve Girişimcilik Niyeti}

Girişimci kavramı, Latince intare kökünden geldiği, İngilizce'de enter (giriş) ve pre (ilk) kelime köklerinin birleşmesi ile oluşan entrepreneur, yani "ilk girişen, başlayan" olarak 
tanımlanmaktadır (Yılmaz, 2014:299). Girişimciliğin ve girişimcinin alan yazında pek çok tanımı bulunmakla beraber, girişimciliğin ve girişimcinin ilk olarak 1755 yılında Richard Cantilon tarafından yapılan tanımı geniş kabul görmüştür. Cantilon'a göre girişimci; "kâr elde etmek amacıyla işi organize eden ve işin risklerini üstlenen kişi" olarak tanımlanmıştır (Korkmaz, 2012:2).

Girişimcilik, "gerekli zaman ve çabayı adayarak, beraberindeki finansal, psikolojik ve sosyal riskleri üstlenerek ve bunun sonucunda elde edilen parasal ve kişisel memnuniyet ödülünü alarak değerli farklı bir şey yaratma sürecidir" (Hisrich, 1986; Shane ve Venkataraman, 2000). Yönetim Akademisine göre girişimcilik, "yeni işletmelerin, küçük işletmelerin ve aile işletmelerinin oluşturulması ve yönetimi"dir (Coulter 2003:4). Girişimcilik, mevcut kaynaklara bakılmaksızın bir fırsat arayışıdır ve girişimciler kendilerini bu fırsatların takipçileri olarak algilarlar (Stevenson vd., 1989).

Klasik anlamda girişimci, bir işletmenin faaliyetlerinden kaynaklanan riski, sorumluluğu ve örgüt yönetimini üstlenen kişi olarak kabul edilmekteyse de bilgi toplumuyla birlikte, kavram yeniden tanımlanarak yenilik üreten, risk alan, fırsat yakalayan ve bunları hayata geçiren kişi olarak kabul edilmiştir. Dolayısıyla, girişimcinin değişen tanımında belirleyici unsur yenilik kavramı olmuştur (Ercan ve Gökdeniz 2009:9). Drucker'e göre yenilik girişimciliğin özel bir fonksiyonudur. Girişimciler yeniliklerin yaratılmalarına, yayılmalarına ve de uygulanmalarına öncülük eder ve hız kazandırırlar (Drucker'dan aktaran Tikici ve Aksoy, 2009:26).

Bir kuruluşun küçük olması onu otomatik olarak girişimci yapmamaktadır (Coulter 2003). Carland ve arkadaşları (1988), küçük işletme sahipleri ile girişimcilerin aynı olmadığını öne sürmektedirler. Girişimciliğin, bir yeniliğin büyümesine yönelik bir girişim stratejisi ile küçük işletme sahipliğinden ayırt edilebileceğini önermektedirler. Girişimciler farklı kişilik özellikleri ve davranış tercihleri ile karakterize edilmektedirler. Girişimcilik teşebbüsü, kuruluşların stratejik davranışlarıyla tanımlanmaktadır (Carland vd., 1988). Vesper (1980) beş davranış kategorisini desteklemiştir;

(1) Yeni malların tanitımı

(2) Yeni üretim yönteminin tanitılması

(3) Yeni pazarların açılması

(4) Yeni tedarik kaynaklarının açılması

(5) Endüstriyel yeniden yapılanma

Bu kriterler yenilikçi stratejilerin kanıtlarını temsil etmektedirler ve bir firmanın kendi çıkarlarına uygun davranışı üzerinde durmaktadırlar (Carland vd., 1984).

Girişimcilik teşebbüsü, yenilikçi stratejik uygulamalarla karakterize edilmekte ve temel hedefi kârlılık ve büyümedir. Bir girişimci, kâr ve büyümenin temel amaç olduğu ve yenilikçi davranışlarla karakterize edilen bir iş kurmakta ve yönetmektedir (Carland vd., 1984).

Ekonomi ve işletme alanında girişimcilik, işsizliğin önlenmesinde, ekonomik büyümenin hızlandırılmasında ve toplumsal yapıda değişimci/yenilikçi bir sürecin başlatılmasında temel faktör olarak görülmektedir. Bu bağlamda girişimcilik potansiyeline sahip bireylerin sahaya çıarılabilmesi büyük önem taşımaktadır (Uslu, 2015:33).

Girişimciliğin ortaya çıkışında kişiliğin mi, yoksa sosyal çevrenin mi daha etkili olduğu sorusu uzun süre tartışılmıştır (Ören ve Biçkes 2011:72).

"Girişimcilik doğuştan mıdır, yoksa sonradan mı oluşur?" tartışmaları yapılırken insanın girişimci olarak doğmadığı; var olan potansiyelin kültürel, sosyolojik, psikolojik, sosyo-psikolojik, politik 
ve ekonomik çevre faktörleriyle bireylere kazandırıldığı inancı yaygınlaşmıştır. İnsanda girişimciliğin etkileri genetik olarak var olabilir. Ancak ailenin, çevrenin ve eğitimin de girişimci kişiliğin oluşmasında çok önemli etkenler olduğunun bilinmesi gerekir (Bozkurt vd., 2012).

Girişimcilik, planlı ve niyetli davranışları temsil etmektedir. Niyet literatürü iki kavram önermektedir; ilk olarak, niyetler karar vericilerin dikkatini hedef davranışa odaklamaya hizmet etmektedirler ve bu davranışı etkileyen tek davranışı kabul etmektedirler (Bird, 1988). İkincisi, sosyal normlar, algılanan davranışsal kontrol ve öz yeterlilik gibi niyetleri öngören kilit tutumlar alg1 tabanlıdır (Ajzen, 1991; Bandura, 1986). Bu nedenle, öğrenilmekte ve öğrenilebilmekte ve hem bireylere hem de durumlara göre değişebilmektedir (Krueger ve Brazeal, 1994).

Girişimcilik niyetlerinin ampirik analizleri giderek yaygınlaşmaktadır (Autio vd., 2001; Chen vd., 1998; Erikson, 1999; Fayolle vd., 2006; Kickul ve Zaper, 2000; Kolvereid, 1996; Kolvereid ve Isaksen, 2006; Krueger, 1993; Krueger ve Brazeal, 1994; Krueger vd., 2000; Lee ve Wong, 2004; Peterman ve Kennedy, 2003; Reitan, 1998; Tkachev ve Kolvereid, 1999; Veciana vd., 2005; Zhao vd., 2005). Çoğu kendi ad hoc (amaca özel, niyete mahsus) araştırma (belli bir amaca yönelik, belli durumları ölçmek için yapılan araştırmalar) araçlarını geliştirmiştir (Chandler ve Lyon, 2001). Bu çalışmalar arasındaki karşılaştırmalar oldukça sorunlu hale gelmiştir, çünkü yapı ölçütleri arasındaki farklılıklar bazen önemli olmaktadır. Bu nedenle, Liñán ve Chen (2009) istatistiksel ve teorik olarak sağlam bir önlem oluşturma görevini üstlenmektedir. Söz konusu çalışmada (Liñán ve Chen, 2009) girişimci niyeti modeli uygulanarak bilişsel yaklaşım izlenmektedir.

\section{Yenilik ve Yenilikçi Davranış}

Yenilikle ilgili yapılan araştırmalarda karşılaşılan en büyük zorluklardan biri yeniliğin ne olduğunu ortaya koyacak genel bir tanımın olmayışıdır (Goswami ve Mathew, 2005). Ancak birçok tanımın ortak noktasında yeniliğin, yeni ve özgün olanla ilgili olduğu görülmektedir. Bunun yanında yenilik sadece özgün fikirlerin ortaya konulmasını değil, aynı zamanda bunların geliştirilmesini, yayılmasını ve uyarlanmasını da içermektedir (Damanpour, 1991).

Yenilikle ilgili olarak yapılan çözümlemelerde, yeniliğin değeri katma değer yaratmasıyla yakından ilişkili olduğu görülmektedir (Goswami ve Mathew, 2005) ve örgütsel anlamda yeniliğin örgütün performansına bir şekilde katkıda bulunması beklenmektedir (Read, 2000). Bu anlamda ortaya konulan her yeni fikrin yenilik ya da inovasyon olarak adlandırılması mümkün değildir. Ortaya konulan fikrin pratik bir maliyetle ve güvenilir olarak çoğaltılabilir olması halinde yenilikten söz edilebilir (Senge, 2000).

Yenilikçi davranış ise, yeni fikirlerin üretilmesi, yaratılması, geliştirilmesi, uygulanması, teşvik edilmesi, fark edilmesi ve tanımlanması süreci olarak ifade edilmektedir (Thurlings vd., 2015). Dyer vd., (2011) dünyanın en yenilikçi liderlerini inceledikten sonra yenilikçi davranışın sorgulama, gözlemleme, bağlantı kurma, tecrübe etme ve uzlaştırma gibi boyutlardan oluştuğunu tespit etmişlerdir. Bu anlamda yenilikçi davranış gösteren bireylerin mevcut durumu farklı yönleriyle değerlendirerek sorguladıkları, bu durumla ilgili olarak en doğru çıkarımları yapmak adına gözlemlerde bulundukları, ortaya çıkardıkları bulguları diğer örgüt üyeleriyle paylaşarak kendilerine destek aradıkları, yeni ortaya çıan fikirleri uygulamaya dökerek örgütün yeniliği deneyimlemesini sağladıkları ve son olarak bu deneyimin örgütte kalıcı olması ve böylece rekabet avantajının elde edilmesi için uğraştıkları söylenebilir. Örgütlerin sürdürülebilir başarıyı elde etmelerinde yeni fikirler üretmeleri, bu fikirleri uygulamaya dökecek mekanizmaları oluşturmaları ve sürekli değişen çevre şartlarına uyum sağlamak için ortaya çıkan fırsatları değerlendirmeleri gerekmektedir (Çimen ve Yücel, 2017:368). 
Hem bilim adamları hem de uygulayıcılar, bireysel çalışanların örgütsel başarı için yenilikçi çalışma davranışının "Innovative Work Behaviour (IWB)" önemini vurgulamakla birlikte, IWB'nin ölçümü hâlâ evrimsel bir aşamadadır. Bir çalışma dört potansiyel boyutta bir IWB ölçüsü geliştirmeyle ilgilidir: fikirlerin araştırılması, oluşturulması, savunulması ve uygulanması (De Jong ve Den Hartog, 2010:23).

Yenilikçi çalışma davranışının (IWB) çok boyutlu bir ölçüsü geliştirilerek bireysel inovasyon araştırmaları alanına katkıda bulunmak amaçlanmaktadır. Önceki literatürde genellikle yaratıcılık (fikirleri keşfetme ve üretme dâhil) ve yenilikçilik (fikirleri destekleme ve uygulama dâhil) arasında bir ayrım yapılmaktadır (De Jong ve Den Hartog, 2010:23). Bununla birlikte, diğerleri, bireylerin yenilikçi çalışma davranışlarının tek ölçülerinde fikirlerin üretilmesini ve uygulanmasını içermektedir (Örneğin, Van de Ven, 1986; Scott ve Bruce, 1994). İlk çalışmalar esas olarak yaratıcı fikirlerin üretilmesine odaklanırken, son zamanlarda araştırmacılar kapsamın genişletilmesini ve fikirlerin uygulanmasına daha fazla bilimsel dikkatin verilmesini istemektedir (Ör. Mumford, 2003). Buna paralel olarak, IWB'nin şu anda tipik olarak fikir üretme, onlara destek oluşturma ve bunların uygulanmasına yardımcı olma ile ilgili geniş bir dizi davranışı kapsadığg görülmektedir (Örn. Scott ve Bruce, 1998; Janssen, 2000).

Her ne kadar IWB teorik olarak çok boyutlu olarak ele alınsa da mevcut IWB ölçümleri çoğunlukla tek boyutludur (Örneğin, Scott ve Bruce, 1994; Reuvers vd., 2008).

Yenilikle ilgili olarak genel bir teori bulunmamasına rağmen bu çalışmada Amabile'in (1988) sistem teorisi yaklaşımı esas alınmaktadır. Buna göre yenilik süreci, örgütün farklı birimlerinde çalışan bireylerin yeni bir fikri uygulamak için bir araya gelerek çalışmasını esas alan bir sistemin içinde ilerlemektedir. Bu sistem içinde yenilikçi bir kültürün oluşturulmasında örgütteki her bir bireyin yaratıcılık ve yenilik kapasitesi önemlidir. Bu nedenle yeniliği etkileyebilecek bütün unsurların bir arada ele alınması gerekliliği ortaya çıkmaktadır.

Yenilikçilik: Bir fikir ya da kavramı ürün ya da hizmet üretimine dönüştürmeyi ifade etmektedir. Schumpeter (1934) ise girişimciyi, yenilikçi bir kişi olarak tanımlamaktadır. Yenilikçilik, girişimciliğin temelini oluşturmaktadır. Böylelikle girişimciler yeni ürün, yeni organizasyon yapısı, yeni ürün süreçleri ve yeni bir şirket yapısıyla işe başlamaktadırlar (Korkmaz, 2012:5). Drucker'e göre, yenilik girişimciliğin özel bir fonksiyonudur. Buna göre girişimcilik açısından yenilik; işletmenin ekonomik ve sosyal potansiyele odaklı değişimler yaratma faaliyetidir. Yenilikçilik, girişimci kişilik özellikleri arasında en fazla üzerinde durulan ve girişimci kişilerde olması gerektiği konusunda hemfikir olunan kişilik özelliğini ifade etmektedir (Tikici ve Aksoy, 2009:16). Çünkü girişimci, yenilikçilik yönüyle değişimleri ortaya çıarmakta, farkındalık yaratmakta ve bunun sonucunda da başarıya ulaşmaktadır (İşcan ve Kaygın, 2011).

\section{ARAŞTIRMA}

\section{Problem Durumu}

Örgütteki çalışanların yenilikçi davranışlarını artırmak için bunları etkileyen faktörlerin bilinmesi gerekir (Damanpour, 1991). Bu anlamda yapılacak çalışmalardan biri de kamu ve özel sektörde çalışanların yenilikçi davranış algılarını belirlemek ve bu algı ile ilişkili olabileceği düşünülen kavramları test etmektir.

Alan yazındaki bazı araştırmalarda (Kristiansen ve Indarti, 2004; Liñán ve Chen 2009; Göksel ve Aydıntan, 2011) demografik özellikler ile kişilik özellikleri bireylerin girişimcilik niyetlerini etkileyen önemli faktör olarak görülmektedir. Bu nedenle, araştırmada girişimcilik niyetine etkisinin olduğu düşünülen girişimci kişilik özelliklerinden olan yenilikçi davranış faktörü 
demografik özelliklerle birlikte ele alınıp incelenirken aynı zamanda aile geçmişinin etkileri de dikkate alınarak analizler yapılmıştır. Araştırmanın problem cümleleri şu şekilde oluşturulmuştur:

“Kamu ve özel sektörde çalışanların girişimcilik niyeti tutumunda kurumda çalışanların göstermiş oldukları yenilikçi davranışlar nelerdir?", "Aile geçmişinin kamu ve özel sektörde çalışanların göstermiş oldukları yenilikçi davranışlar ile girişimcilik niyeti tutumları üzerindeki etkileri nelerdir?".

\section{Araştırmanın Amacı}

$\mathrm{Bu}$ araştırmanın temel amacı; kamu ve özel sektörde çalışanların göstermiş oldukları yenilikçi davranışlar ile girişimcilik niyeti tutumlarının demografik özellikler açısından incelenmesinde aile geçmişinin etkilerini araştırmaktır. Bu temel amaç doğrultusunda belirlenen alt amaçlar ise şöyledir:

1. Kamu ve özel sektörde çalışanların girişimcilik niyeti demografik özelliklerine göre farklılık göstermekte midir?

2. Kamu ve özel sektörde çalışanların yenilikçi davranışları demografik özelliklerine göre farklılık göstermekte midir?

3. Ebeveynleri girişimci olan bireyler ile ebeveynleri girişimci olmayan bireyler arasında girişimcilik niyeti açısından farklılık var mıdır?

4. Kamu ve özel sektörde çalışanların yenilikçi davranışları ile girişimcilik niyeti arasında ilişki var midır?

\section{Araştırmanın Önemi}

Yenilikçi davranışların ve girişimcilik niyetinin kişisel ve demografik özelliklerle arasındaki ilişkilerin ve bu özelliklerin kişilerin yenilikçi davranışlarını ve girişimcilik niyetlerini nasıl etkilediği konusunda aile geçmişinin etkilerinin araştırılması kurumların gelişimi ve girişim sayısının artması bakımından önemlidir.

Kamu sektöründe çalışanların yenilikçi fikirler öne sürmeye ne ölçüde açık oldukları ve girişimcilik niyetleri araştırılmalıdır.

$\mathrm{Bu}$ araştırma sonucunda kamu ve özel sektörde çalışanların yenilikçi davranışlarını çalışma arkadaşlarının gözünden yorumlamak ve dolayısıyla örgütsel anlamda fikir edinebilmek amaçlanmaktadır.

Yeniliğin giderek önem kazandığı günümüzde kurumların ve çalışanların da yenilikçi bir anlayışa sahip olmaları ve toplumun bu yöndeki beklentilerini karşılamaları gerekmektedir. Bu anlamda çalışanların yenilikçi davranışları benimsemesi ve bu çerçevede kendilerini geliştirmeleri önemlidir. Ancak bunun için atılacak adımlarda ilk olarak çalışanların yenilikçi davranışları ne ölçüde gösterdiklerini belirlemek araştırmacılara ve uygulayıcılara geliştirilecek programlar konusunda yol gösterici olacaktır. Bu anlamdaki eksikliği gidereceği düşünülmektedir. 


\section{Araştırmanın Kısıtlılıkları}

Çalışmamıza Ankara ve İstanbul İllerindeki kamu ve özel sektörde faaliyet gösteren kurum ve kuruluşlarda çalışan personelin katılmış olması çalışmanın en önemli kısıtlılı̆̆ını oluşturmaktadır.

Pandemi süreci kapsamında Ankara ve İstanbul İllerindeki 600 katılımcıya online olarak ölçek formları gönderilmiş ve bu sürecin etkilerinden dolayı geriye dönen 253 ölçek formu olmuştur. Diğer taraftan süre kısıtından dolayı 246 ölçek formu üzerinden gerekli analiz ve incelemeler yapılmıştır. Örneklem sayısı artırılarak ve/veya farklı iller ve bölgeler seçilerek araştırma yeniden gerçekleştirilebilir.

\section{Araştırmanın Yöntemi}

Araştırmanın amacına uygun verileri toplamak için nicel araştırma yöntemlerinden anket tekniği kullanılmıştır. Oluşturulan veri toplama aracı 3 (üç) bölümden oluşmaktadır. Birinci bölümde demografik özellikler, ikinci bölümde girişimcilik niyeti anketi ve üçüncü bölümde yenilikçi davranış anketi yer almaktadır. Birinci bölümde kamu ve özel sektör çalışanlarının demografik bilgilerini belirlemek amacıyla 16 (on altı) soru yer almaktadır. İkinci ve üçüncü bölümlerde beşli Likert olarak hazırlanmış olan anketler toplam 16 (on altı) maddeden oluşmaktadır.

Çalışanların girişimcilik niyetleri için, Liñán ve Chen (2009) tarafından geliştirilen ve Şeşen ve Basım (2012) tarafından Türkçe'ye uyarlanan 6 (altı) maddeden oluşan ölçek kullanılmıştır. Yüksek puanın girişimcilik niyetinin yüksekliğine işaret ettiği ölçek, Hiçbir Zaman'dan (1), Her Zaman'a (5) kadar uzanan, 5'li Likert tipi bir ölçme aracıdır.

Örgütsel anlamda bireylerin yenilikçi davranışlarını değerlendirmek amacıyla geliştirilen ve özgün formu "Innovative Work Behaviour (IWB)" olarak adlandırılan ölçek 2010 yılında De Jong ve Den Hartog tarafından geliştirilmiştir. Ölçeğin özgün dili İngilizce'dir. Türkçe'ye ise Çimen ve Yücel (2017) tarafından uyarlanmıştır. Ölçeğin özgün formunda 10 (on) madde ve 4 (dört) boyut bulunmaktadır. Bu 4 (dört) boyut "fikir üretme (madde 1 ve 2)", "araştırma (madde 3, 4 ve 5)”, "destekleme (madde 6 ve 7) ve "uygulama (madde 8, 9 ve 10) olarak belirtilmiştir. Ölçek beşli Likert olarak hazırlanmış ve katılımcılardan örgütteki diğer insanların yenilikçi davranışları gösterme sıklıklarını "Hiçbir Zaman" ve "Her Zaman" aralığında belirtmeleri istenmiştir.

Ölçeğin “fikir üretme" boyutunda yeni ürünlerin, hizmetlerin ya da süreçler üzerinde düşünmek, yeni bir hizmet alanına girmek, mevcut iş süreçlerini geliştirmek ya da belirlenen problemlere çözümler getirmek esas alınmaktadır. "Araştırma" boyutu mevcut ürünlerin, hizmetlerin ya da süreçlerin geliştirilmesi için çözümler aramayı ve bunlarla ilgili alternatif yollar bulmayla ilgilidir. "Destekleme" ise yeni bir fikir ortaya atılıp olgunlaştığında ön plana çıkmaktadır. Bu boyut, yeni fikirlerin önündeki engelleri kaldıracak informel rollerin benimsenmesini ve yenilikçi adımların başarıya ulaştırılması için destek görmesini içermektedir. "Uygulama" boyutunda ortaya çıkan fikirlerin sonuç odaklı bir anlayışla hayata geçirilmesi yer almaktadır (De Jong ve Den Hartog, 2010).

\section{Araştırmanın Evreni}

Araştırmanın evreni, Ankara ve İstanbul İllerinde ve farklı kademelerde olmak üzere görev yapmakta olan kamu ve özel sektör çalışanından oluşmaktadır. Bu nedenle de Ankara ve İstanbul İllerindeki 600 katılımcıya online olarak ölçek formları gönderilmiş ve geriye dönen 253 ölçek 
formu araştırmaya dâhil edilmiştir. Ancak veriler gözden geçirilirken 7 katılımcının formundaki eksikliklerden dolayı bunlar veri analizinden çıkarılmıştır.

\section{Araştırmanın Hipotezleri}

1. Kamu ile özel sektör çalışanları arasında girişimcilik niyeti açısından anlamlı farklılık vardır.

2. Kamu ve özel sektörde çalışanların girişimcilik niyeti yaşa göre farklılık göstermektedir.

3. Kamu ve özel sektörde çalışanların girişimcilik niyeti cinsiyete göre farklılık göstermektedir.

4. Kamu ve özel sektörde çalışanların girişimcilik niyeti medeni duruma göre farklılık göstermektedir.

5. Kamu ve özel sektörde çalışanların girişimcilik niyeti eğitim düzeyine göre farklılık göstermektedir.

6. Birinci Derece Akrabaları (Anne, Baba, Çocuk) girişimci olan bireyler, Birinci Derece Akrabaları (Anne, Baba, Çocuk) girişimci olmayanlardan daha yüksek girişimci niyetlerine sahip olacaktır.

7. İkinci Derece Akrabaları (Kardeş, Dede, Nine, Torun) girişimci olan bireyler, İkinci Derece Akrabaları (Kardeş, Dede, Nine, Torun) girişimci olmayanlardan daha yüksek girişimci niyetlerine sahip olacaktır.

8. Üçüncü Derece Akrabaları (Amca, Dayı, Hala, Teyze, Yeğen) girişimci olan bireyler, Üçüncü Derece Akrabaları (Amca, Dayı, Hala, Teyze, Yeğen) girişimci olmayanlardan daha yüksek girişimci niyetlerine sahip olacaktır.

9. Kamu ile özel sektör çalışanları arasında yenilikçi davranışlar açısından anlamlı farklılık vardir.

10. Kamu ve özel sektörde çalışanların yenilikçi davranışları yaşa göre farklılık göstermektedir.

11. Kamu ve özel sektörde çalışanların yenilikçi davranışları cinsiyete göre farklılık göstermektedir.

12. Kamu ve özel sektörde çalışanların yenilikçi davranışları medeni duruma göre farklılık göstermektedir.

13. Kamu ve özel sektörde çalışanların yenilikçi davranışları eğitim düzeyine göre farklılık göstermektedir.

14. Yenilikçi davranışlar girişimcilik niyetini anlamlı ve pozitif bir şekilde etkiler.

\section{Araştırmanın Bulguları}

Araştırma sonucunda elde edilen bulgular aşağıda açıklanmıştır.

\section{Demografik Faktörler}

Araştırmaya katılanlar daha çok 40-50 yaş aralığındadır (N:111; \%45,1). Daha sonrasında ise 2939 yaş aralığındadır (N:104; \%42,3). En az ise $18-28$ yaş aralığındadır (N:13; \%5,3). Yaş ortalamaları incelendiğinde ise, girişimcilik niyetinin yaş ortalaması 2,7486 ve yenilikçi davranış yaş ortalaması ise 2,9268' dir. Eğitim durumlarında ise en çok ön lisans-lisans düzeyindedir (N:136; \%55,3). En az ise ilkokul-ortaokul-lise düzeyindedir (N:10; \%4,1). Cinsiyet açısından ise 76 'sı $(\% 30,9)$ kadın ve 170 'i $(\% 69,1)$ ise erkektir. Katılanların 186's1 $(\% 75,6)$ evli ve 60' $1(\% 24,4)$ ise bekârdır. Katılımciların 158'si $(\% 64,2)$ kamu sektöründe, 63'ü $(\% 25,6)$ özel sektörde ve 25'i 
$(\% 10,2)$ ise kendi işinde çalışmaktadır. Katılımcıların 84 'ünün birinci derece akrabalarının girişimci oldukları, 148'inin ikinci derece akrabalarının girişimci oldukları ve 65'inin ise üçüncü derece akrabalarının girişimci oldukları sonucuna ulaşılmıştır. Araştırmaya katılanların demografik faktörlerine yönelik sonuçlar aşağıdadır.

Tablo 1. Araştırma Örneğinin Demografik Faktörleri

\begin{tabular}{|c|c|c|c|}
\hline & & $\mathrm{n}$ & $\%$ \\
\hline \multirow{5}{*}{ 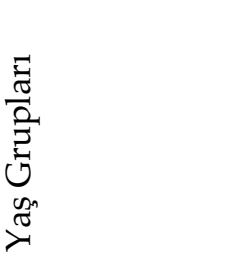 } & $18-28$ & 13 & 5,3 \\
\hline & $29-39$ & 104 & 42,3 \\
\hline & $40-50$ & 111 & 45,1 \\
\hline & 51 ve üzeri & 18 & 7,3 \\
\hline & Toplam & 246 & 100,0 \\
\hline \multirow{5}{*}{ 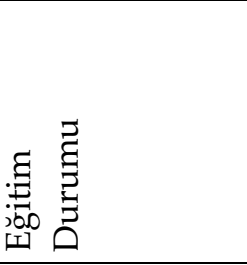 } & İlkokul-Ortaokul-Lise & 10 & 4,1 \\
\hline & Ön Lisans-Lisans & 136 & 55,3 \\
\hline & Yüksek Lisans & 74 & 30,1 \\
\hline & Doktora & 26 & 10,6 \\
\hline & Toplam & 246 & 100,0 \\
\hline \multirow{3}{*}{ 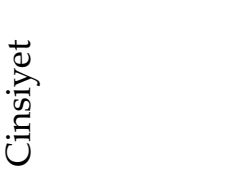 } & Kadın & 76 & 30,9 \\
\hline & Erkek & 170 & 69,1 \\
\hline & Toplam & 246 & 100,0 \\
\hline \multirow{3}{*}{ 总 } & Evli & 186 & 75,6 \\
\hline & Bekâr & 60 & 24,4 \\
\hline & Toplam & 246 & 100,0 \\
\hline \multirow{4}{*}{ 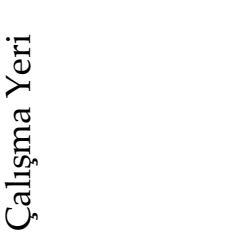 } & Kamu & 158 & 64,2 \\
\hline & Özel & 63 & 25,6 \\
\hline & Kendi İşim & 25 & 10,2 \\
\hline & Toplam & 246 & 100,0 \\
\hline \multirow{3}{*}{$\begin{array}{l}\text { Birinci Derece } \\
\text { Akraba }\end{array}$} & Evet & 84 & 34,1 \\
\hline & Hayır & 162 & 65,9 \\
\hline & Toplam & 246 & 100,0 \\
\hline \multirow{3}{*}{$\begin{array}{l}\text { İkinci } \\
\text { Derece } \\
\text { Akraba }\end{array}$} & Evet & 148 & 60,2 \\
\hline & Hayır & 98 & 39,8 \\
\hline & Toplam & 246 & 100,0 \\
\hline \multirow{3}{*}{$\begin{array}{l}\text { Üçüncü Derece } \\
\text { Akraba }\end{array}$} & Evet & 65 & 26,4 \\
\hline & Hayır & 181 & 73,6 \\
\hline & Toplam & 246 & 100,0 \\
\hline
\end{tabular}

\section{Doğrulayıcı Faktör Analizi (DFA)}

Doğrulayıcı faktör analizi iki aşamada gerçekleştirilmiştir. Yapılan ilk analizde bazı model uyum değerleri kabul edilebilir seviyenin altında ve bazı ifadelerin faktör yükleri 0,50'nin altında çıkmıştır. Bu nedenle, DFA modelinde bazı düzeltmeler yapılmıştır. İlk analiz sonucunda elde 
edilen model uyum değerleri şu şekildedir: $\mathrm{CMIN} / \mathrm{DF}=\mathbf{2 , 7 8 1}$, RMR=0,082, GFI=0,725, CFI=0,849, RMSEA=0,085. İlk analiz sonucunda; girişimcilik niyeti 1 ve girişimcilik niyeti 2; yenilikçi davranış 1 ve yenilikçi davranış 3; yenilikçi davranış 4 ve yenilikçi davranış 5; yenilikçi davranış 6 ve yenilikçi davranış 7 nolu ifadeler birleştirilmiştir. Düşük faktör yükü nedeniyle yenilikçi davranış 2 nolu ifade analizden çıkarılmıştır. Bu işlemlerden sonra analiz tekrar yapılmıştır ve nihai sonuçlar aşağıda sunulmuştur.

Tablo 2. DFA Sonuçları

\begin{tabular}{|c|c|c|c|}
\hline \multicolumn{3}{|c|}{ İfadeler ve Değişkenler } & \multirow{2}{*}{$\begin{array}{r}\text { Faktör Yükleri } \\
, 955^{* * *}\end{array}$} \\
\hline GirişimcilikNiy6 & $<---$ & GİRİ̧İMCİLİK NİYETİ & \\
\hline GirişimcilikNiy5 & $<--$ & GİRIŞiMCİLIK NİYETİ &, $925^{* * *}$ \\
\hline GirişimcilikNiy4 & $<---$ & GİRIŞİMCİLİK NİYETİ &, $955^{* * *}$ \\
\hline GirişimcilikNiy3 & $<--$ & GİRİŞIMCİLIKK NİYETİ &, $884^{* * *}$ \\
\hline GirişimcilikNiy2 & $<---$ & GİRİŞIMCİLİK NİYETİ &, $804^{* * *}$ \\
\hline GirişimcilikNiy1 & $<--$ & GİRİŞIMCİLİK NİYETİ &, $681^{* * *}$ \\
\hline YenilikçiDav10 & $<--$ & YENİLIKÇİ DAVRANIŞ &, $934^{* * *}$ \\
\hline YenilikçiDav9 & $<--$ & YENİLIKÇİ DAVRANIŞ &, $927^{* * *}$ \\
\hline YenilikçiDav8 & $<---$ & YENİLIKÇİ DAVRANIŞ &, $926^{* * *}$ \\
\hline YenilikçiDav7 & $<--$ & YENİLIKÇİ DAVRANIŞ & $893^{* * *}$ \\
\hline YenilikçiDav6 & $<---$ & YENİLIKÇİ DAVRANIŞ &, $872^{* * *}$ \\
\hline YenilikçiDav5 & $<--$ & YENİL̇KÇİ DAVRANIŞ &, $846^{* * *}$ \\
\hline YenilikçiDav4 & $<--$ & YENİLİKÇİ DAVRANIŞ &, $811^{* * *}$ \\
\hline YenilikçiDav3 & $<--$ & YENİLIKÇİ DAVRANIŞ &, $744^{* * *}$ \\
\hline YenilikçiDav1 & $<--$ & YENİLİKÇİ DAVRANIŞ &, $529^{* * *}$ \\
\hline
\end{tabular}

*** 0,001 düzeyinde anlamlıdır.

Yapılan analizler sonucunda, faktör yükleri 0,50’nin üstündedir. Her faktör yükünün anlamlılık düzeyleri 0,001 olarak tespit edilmiştir.

\section{Model Uyum Değerleri}

CMIN/DF değeri, 3'ün altında olması durumunda mükemmel uyum göstermektedir. Bu çalışmada elde edilen sonuç, 2,044 olarak belirlenmiştir (Hair vd., 2010). RMR değeri için mükemmel uyum düzeyi 0,05 ve altı olarak kabul edilmiştir (Hair vd., 2010). Bayram (2010)'a göre kabul edilebilir düzey, 5 ile 10 arası olarak ifade edilmiştir. Yapılan analiz sonucunda RMR değeri 0,081 olarak tespit edilmiştir. GFI değerinin 0,90'ın üstünde olması istenir ve bu düzey mükemmel uyum değeri olarak dikkate alınır (Hair vd., 2010). Greenspoon ve Saklofske (1998)'e göre, GFI değerinin 0,80'in üstünde olması kabul edilir uyum düzeyi için yeterli görünmektedir. Bu çalışmada, GFI değeri 0,827 olarak belirlenmiştir. Modelleme çalışmalarında dikkate alınan önemli uyum değerlerinden birisi de CFI indeksidir. Bu değer için mükemmel uyum düzeyi 0,95'in üstü olarak ifade edilmiştir (Hair vd., 2010; Bayram, 2010). Ancak, bu indeks için 0,90'ın üstü kabul edilebilir seviyeyi işaret etmektedir. Bu çalışmada CFI değeri, 0,931 olarak tespit edilmiştir. Son olarak, model çalışmalarında RMSEA değeri de dikkate alınmaktadır. RMSEA 
değeri için mükemmel uyum düzeyi 0,05 ve altıdır (Hair vd., 2010; Bayram, 2010). Kabul edilebilir düzeyde ise, 0,08'e kadar bu katsayı çıkabilmektedir. Analiz sonucunda, RMSEA değeri 0,061 olarak belirlenmiştir.

\section{Hipotezlerin Testi}

Araştırmanın modeli aşağıdadır.

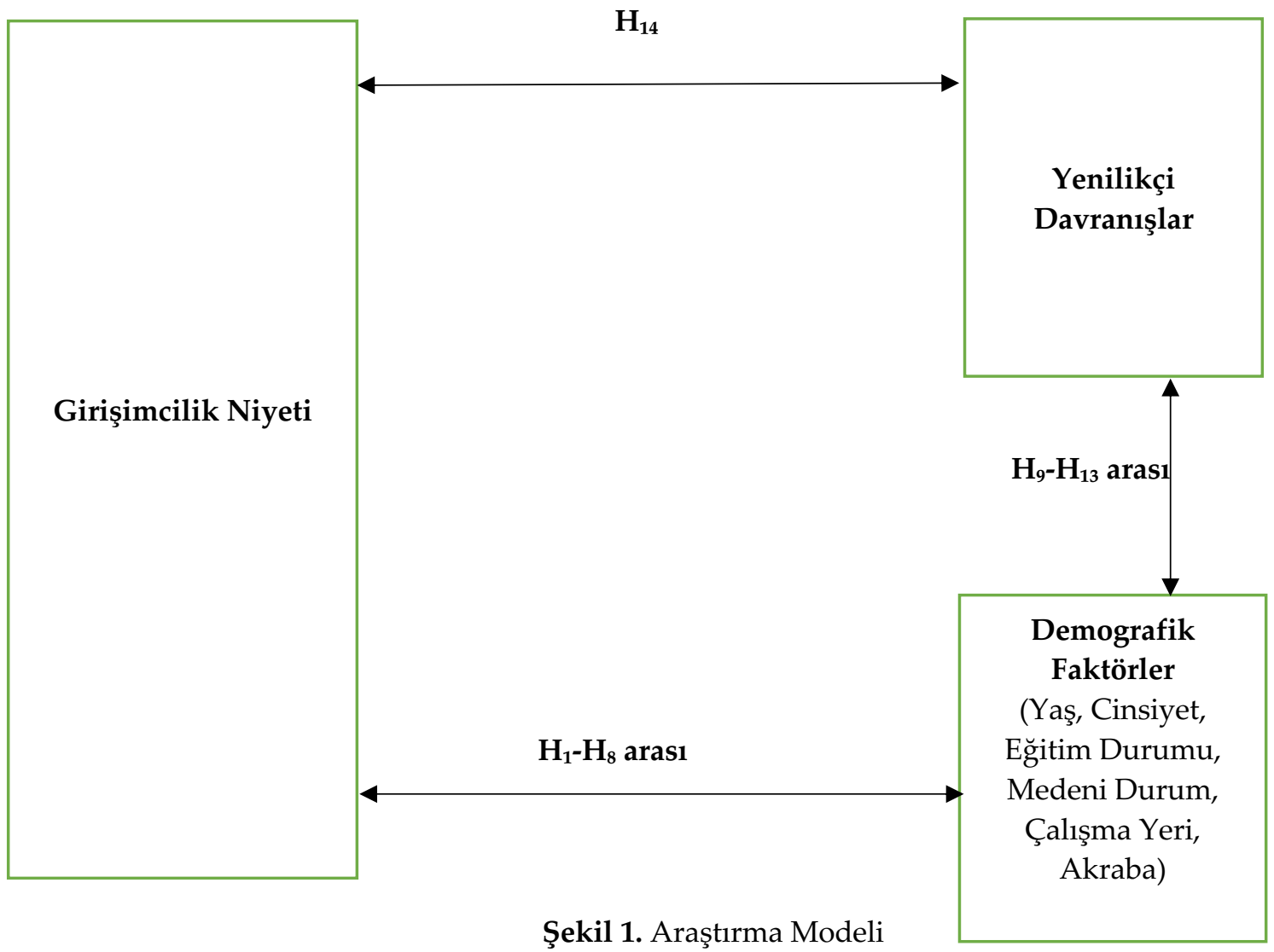

Hipotezleri test etmek için farklılık testleri, varyans analizleri, anova testleri, Scheffe Post-Hoc testi, Levene's testleri, $\mathrm{t}$ testleri, korelasyon analizleri ve etki analizleri uygulanmıştır. Bunlar sonucunda ulaşılan sonuçlar aşağıdadır.

\section{Farklılık Testleri}

Farklılık testleri kapsamında varyans analizleri, anova testleri, Scheffe Post-Hoc testi, Levene's testleri ve $t$ testleri uygulanmıştır. Bunlar sonucunda ulaşılan sonuçlar aşağıdadır.

\section{Çalışma Yerine Göre Farklılıklar}

Çalışma yerine göre anlamlı farklılık olup olmadığını tespit etmek amacıyla anova testi uygulanmıştır. Buna yönelik sonuçlar aşağıdadır. 
Tablo 3. Çalışma Yerine Göre Farklılıklar (ANOVA TESTI)

\begin{tabular}{|l|r|r|r|c|c|}
\hline \multirow{2}{*}{ Değişkenler } & \multicolumn{2}{|c|}{ ANOVA } & \multicolumn{3}{c|}{ Ortalamalar } \\
\cline { 2 - 6 } & \multicolumn{1}{|c|}{ F } & Anlamlılı & Kamu & Özel & Kendi İşim \\
\hline Girişimcilik Niyeti & 30,063 &, 000 & 2,409 & 3,074 & 4,073 \\
\hline Yenilikçi Davranış & 17,739 &, 000 & 2,674 & 3,372 & 3,404 \\
\hline
\end{tabular}

Yapılan analiz sonucunda çalışma yerine göre anlamlı farklılık vardır. Bu bağlamda, hipotez 1 ve 9 kabul edilmiştir. Farklılığın hangi alanlar arasında olduğunu görmek için Post-Hoc testi yapmak gerekir. Aşağıda Scheffe Post-Hoc testi sonuçları sunulmuştur.

Tablo 4. Scheffe Post-Hoc Testi

\begin{tabular}{|c|c|c|c|c|c|}
\hline $\begin{array}{l}\text { Dependent } \\
\text { Variable }\end{array}$ & $\begin{array}{l}\text { (I) Çalışma } \\
\text { Yeri }\end{array}$ & $\begin{array}{l}\text { (J) Çalışma } \\
\text { Yeri }\end{array}$ & $\begin{array}{l}\text { Ortalama } \\
\text { farklılıkları }\end{array}$ & $\begin{array}{c}\text { Standart } \\
\text { hata }\end{array}$ & Anlamlılık \\
\hline \multirow{6}{*}{$\begin{array}{l}\text { Girişimcilik } \\
\text { Niyeti }\end{array}$} & \multirow[t]{2}{*}{ Kamu } & Özel &,$- 66479^{*}$ &, $\mathbf{1 5 9 3 2}$ & ,000 \\
\hline & & Kendi İşim & $-1,66405^{*}$ & 23014 & , 000 \\
\hline & \multirow[t]{2}{*}{ Özel } & Kamu & ,66479 & 15932 & ,000 \\
\hline & & Kendi İşim &,$- 99926^{*}$ & ,25274 & ,001 \\
\hline & \multirow[t]{2}{*}{ Kendi İşim } & Kamu & $1,66405^{*}$ & ,23014 & ,000 \\
\hline & & Özel & ,99926* & ,25274 & , 001 \\
\hline \multirow{6}{*}{$\begin{array}{l}\text { Yenilikçi } \\
\text { Davranış }\end{array}$} & \multirow[t]{2}{*}{ Kamu } & Özel &,$- 69844^{*}$ & ,13313 & , 000 \\
\hline & & Kendi İşim &,$- 73075^{*}$ & 19230 & 001 \\
\hline & \multirow[t]{2}{*}{ Özel } & Kamu & ,69844* & 13313 & 000 \\
\hline & & Kendi İşim &,- 03231 & 21119 & ,988 \\
\hline & \multirow[t]{2}{*}{ Kendi İşim } & Kamu & ,73075 & 19230 & 001 \\
\hline & & Özel & 03231 & 21119, & 988 \\
\hline
\end{tabular}

Yapılan analiz sonucunda, özellikle kamuda çalışan bireylerin girişimcilik niyeti ve yenilikçi davranış konusunda diğerlerinden farklılaştığ 1 görülmektedir. Ortalamalar incelendiğinde, kamuda çalışanların ortalamalarının daha düşük olduğu görülmektedir.

\section{Cinsiyete Göre Farklılıklar}

Cinsiyete göre anlamlı farklılık olup olmadığını tespit etmek amacıyla t testi uygulanmıştır. Buna yönelik sonuçlar aşağıdadır.

Tablo 5. Cinsiyete Göre Farkl1lıklar (T testi)

\begin{tabular}{|c|c|c|c|c|c|c|c|}
\hline \multirow{2}{*}{ Değişskenler } & \multicolumn{2}{|c|}{ Levene's Testi } & \multicolumn{3}{|c|}{ T testi } & \multicolumn{2}{|c|}{ Ortalamalar } \\
\hline & F & Sir & $\mathrm{T}$ & $d f$ & Sig. & Vodu & Fol \\
\hline Girişimcilik Niyeti & ,103 & ,749 & $-1,324$ & 244 & ,187 & 2,599 & 2,816 \\
\hline Yenilikçi Davranış & 255 & 614 & $-1,240$ & 244 & 216 & 2,814 & 2,977 \\
\hline
\end{tabular}


Yapılan $\mathrm{t}$ testi sonucunda, cinsiyete göre anlamlı bir farklılık tespit edilememiştir. Buna göre, hipotez 3 ve 11 reddedilmiştir.

\section{Yaşa Göre Farklılıklar}

Yaşa göre anlamlı farklılık olup olmadığını tespit etmek amacıyla anova testi uygulanmıştır. Buna yönelik sonuçlar aşağıdadır.

Tablo 6. Yaşa Göre Farklılıklar ANOVA (Varyans Analizi)

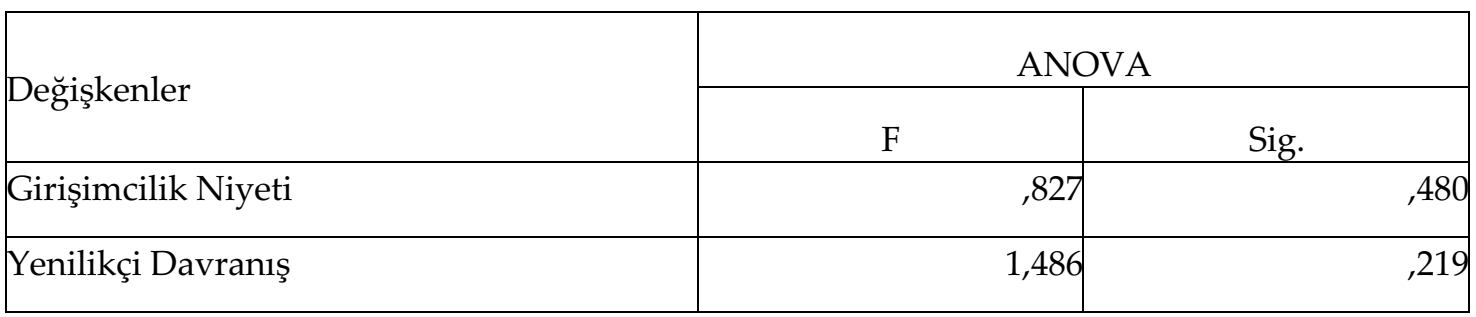

Tablo 7. Yaşa Göre Ortalamalar

\begin{tabular}{|c|c|c|c|}
\hline Yaş Grupları & Analiz Sonuçları & Girişimcilik Niyeti & Yenilikçi Davranış \\
\hline \multirow{3}{*}{$18-28$} & Ortalama & 3,1282 & 3,3761 \\
\cline { 2 - 4 } & Frekans & 13 & 13 \\
\cline { 2 - 4 } & Standart Sapma & 1,02097 &, 84076 \\
\hline \multirow{3}{*}{$29-39$} & Ortalama & 2,7260 & 2,8665 \\
\cline { 2 - 4 } & Frekans & 104 & 104 \\
\cline { 2 - 4 } & Standart Sapma & 1,22318 &, 92216 \\
\hline \multirow{3}{*}{$40-50$} & Ortalama & 2,6847 & 2,9660 \\
\cline { 2 - 4 } & Frekans & 111 & 111 \\
\cline { 2 - 4 } & Standart Sapma & 1,16001 & 1,01568 \\
\hline \multirow{3}{*}{ 51 ve üzeri } & Ortalama & 3,0000 & 2,7099 \\
\cline { 2 - 4 } & Frekans & 18 & 18 \\
\cline { 2 - 4 } & Standart Sapma & 1,29226 & 2,71618 \\
\hline \multirow{3}{*}{ Toplam } & Ortalama & 2,7486 & 246 \\
\cline { 2 - 4 } & Frekans & 246 &, 95252 \\
\cline { 2 - 4 } & Standart Sapma & 1,18931 & \\
\hline
\end{tabular}

Yaşa göre anlamlı bir farklılık tespit edilememiştir. Bu kapsamda, hipotez 2 ve 10 reddedilmiştir.

\section{Medeni Duruma Göre Farklılık}

Medeni duruma göre anlamlı farklılık olup olmadığını tespit etmek amacıyla $t$ testi uygulanmıştır. Buna yönelik sonuçlar aşağıdadır. 
Tablo 8. Medeni Duruma Göre Farkl1lıklar (T Testi)

\begin{tabular}{|c|c|c|c|c|c|c|c|}
\hline \multirow{3}{*}{ Değiş̧kenler } & \multicolumn{2}{|c|}{ Levene's Testi } & \multicolumn{3}{|c|}{ T testi } & \multicolumn{2}{|c|}{ Ortalamalar } \\
\hline & \multirow[b]{2}{*}{$\mathrm{F}$} & \multirow[b]{2}{*}{ Sig. } & \multirow[b]{2}{*}{$\mathrm{T}$} & \multirow[b]{2}{*}{$\mathrm{df}$} & \multirow{2}{*}{$\begin{array}{c}\text { Sig. } \\
\text { (2-tailed) }\end{array}$} & & \\
\hline & & & & & & Evli & Bekâr \\
\hline Girişimcilik Niyeti & ,082 & ,775 & $-2,448$ & 244 & ,015 & 2,644 & 3,072 \\
\hline Yenilikçi Davranış & 3,468 & 064 & 458 & 244 & 647 & 2,943 & 2,878 \\
\hline
\end{tabular}

Yapılan $\mathrm{t}$ testi sonucunda, girişimcilik niyeti değişkeninin medeni duruma göre farklılaştığ görülmektedir. Ortalamalar incelendiğinde, bekârların ortalamalarının evlilerden daha yüksek olduğu görülmektedir. Bu bağlamda, hipotez 4 kabul edilirken hipotez 12 reddedilmiştir.

\section{Eğitim Durumuna Göre Farklılık}

Eğitim durumuna göre anlamlı farklılık olup olmadığını tespit etmek amacıyla anova testi uygulanmıştır. Buna yönelik sonuçlar aşağıdadır.

Tablo 9. Eğitim Durumuna Göre Farklılıklar (ANOVA)

\begin{tabular}{|l|r|r|}
\hline \multirow{2}{*}{ Değişkenler } & \multicolumn{2}{|c|}{ ANOVA } \\
\cline { 2 - 4 } & F & \multicolumn{2}{|c|}{ Sig. } \\
\hline Girişimcilik Niyeti & 2,008 & \\
\hline Yenilikçi Davranış &, 437 &, 727 \\
\hline
\end{tabular}

Tablo 10. Eğitim Durumuna Göre Ortalamalar

\begin{tabular}{|c|c|c|c|}
\hline Eğitim Durumu & Analiz Sonuçları & Girişimcilik Niyeti & Yenilikçi Davranış \\
\hline $\begin{array}{c}\text { İlkokul-Ortaokul- } \\
\text { Lise }\end{array}$ & Ortalama & 3,4167 & 2,9444 \\
\cline { 2 - 4 } & Frekans & 10 & 10 \\
\cline { 2 - 4 } & Standart Sapma & 1,30821 &, 84498 \\
\hline \multirow{3}{*}{ Ön Lisans-Lisans } & Ortalama & 2,7806 & 2,9003 \\
\cline { 2 - 4 } & Frekans & 136 & 136 \\
\cline { 2 - 4 } & Standart Sapma & 1,19768 &, 97610 \\
\hline \multirow{3}{*}{ Yüksek Lisans } & Ortalama & 2,5428 & 2,9024 \\
\cline { 2 - 4 } & Frekans & 74 & 74 \\
\cline { 2 - 4 } & Standart Sapma & 1,15175 &, 95333 \\
\hline \multirow{3}{*}{ Doktora } & Ortalama & 2,9103 & 2,1282 \\
\cline { 2 - 4 } & Frekans & 26 & 268761 \\
\cline { 2 - 4 } & Standart Sapma & 1,13552 & 2,9268 \\
\hline \multirow{3}{*}{ Toplam } & Ortalama & 2,7486 & 246 \\
\cline { 2 - 4 } & Frekans & 246 &, 95252 \\
\cline { 2 - 4 } & Standart Sapma & 1,18931 & \\
\hline
\end{tabular}


Yapılan analiz soncunda eğitim durumuna göre bir farklılık olmadığı görülmüştür. Buna göre, hipotez 5 ve 13 reddedilmiştir.

\section{Birinci Derece Akrabası Girişimci Olanlar ile Olmayanların Girişimcilik Niyeti Açısından Farklılık Olup Olmadı̆̆ı}

Birinci derece akrabası girişimci olanlar ile olmayanların girişimcilik niyeti açısından anlamlı farklılık olup olmadığını tespit etmek amacıyla $t$ testi uygulanmıştır. Buna yönelik sonuçlar aşağıdadır.

Tablo 11. Birinci Derece Akrabası Girişimci Olanlar ile Olmayanların Girişimcilik Niyeti Açısından Farklılıklar (T Testi)

\begin{tabular}{|l|c|c|c|c|c|c|c|}
\hline \multirow{2}{*}{ Değişken } & \multicolumn{2}{|c|}{ Levene's Testi } & \multicolumn{3}{|c|}{ T Testi } & Aile (Ortalama) \\
\cline { 2 - 8 } & $\mathrm{F}$ & Sig. & $\mathrm{T}$ & $\mathrm{df}$ & $\begin{array}{c}\text { Sig. (2- } \\
\text { tailed) }\end{array}$ & Olan & Olmayan \\
\hline Girişimcilik Niyeti & $\mathbf{1 , 4 1 4}$ & $\mathbf{2 3 6}$ & $\mathbf{2 , 9 4 3}$ & $\mathbf{2 4 4}$ & $\mathbf{, 0 0 4}$ & $\mathbf{3 , 1 1 5}$ & $\mathbf{2 , 6 1 7}$ \\
\hline
\end{tabular}

Girişimcilik niyeti açısından birinci derece ailesinde girişimci olanlar ile olmayanlar arasında anlamlı farklılık tespit edilmiştir. Ailesinde girişimci olanların ortalaması daha yüksektir. Bu kapsamda, hipotez 6 kabul edilmiştir.

\section{İkinci Derece Akrabası Girişimci Olanlar ile Olmayanların Girişimcilik Niyeti Açısından Farklılık Olup Olmadığı}

İkinci derece akrabası girişimci olanlar ile olmayanların girişimcilik niyeti açısından anlamlı farklılık olup olmadığını tespit etmek amacıyla $t$ testi uygulanmıştır. Buna yönelik sonuçlar aşağıdadır.

Tablo 12. İkinci Derece Akrabası Girişimci Olanlar ile Olmayanların Girişimcilik Niyeti Açısından Farklılıklar (T Testi)

\begin{tabular}{|l|c|c|c|c|c|c|c|}
\hline \multirow{2}{*}{ Değişken } & \multicolumn{2}{|c|}{ Levene's Testi } & \multicolumn{3}{|c|}{ T Testi } & \multicolumn{2}{c|}{ Aile (Ortalama) } \\
\cline { 2 - 8 } & $\mathrm{F}$ & Sig. & $\mathrm{T}$ & $\mathrm{df}$ & $\begin{array}{c}\text { Sig. (2- } \\
\text { tailed) }\end{array}$ & Olan & Olmayan \\
\hline Girişimcilik Niyeti & $\mathbf{, 0 3 8}$ & $\mathbf{, 8 4 6}$ & $\mathbf{2 , 2 7 4}$ & $\mathbf{2 4 4}$ & $\mathbf{, 0 2 4}$ & $\mathbf{2 , 9 8 6}$ & $\mathbf{2 , 6 2 6}$ \\
\hline
\end{tabular}

Anlamlı farklılık vardır. İkinci derece ailesinde girişimci olanların ortalamaları daha yüksektir. Bu bağlamda, hipotez 7 kabul edilmiştir.

\section{Üçüncü Derece Akrabası Girişimci Olanlar ile Olmayanların Girişimcilik Niyeti Açısından Farklılık Olup Olmadığı}

Üçüncü derece akrabası girişimci olanlar ile olmayanların girişimcilik niyeti açısından anlamlı farklılık olup olmadığını tespit etmek amacıyla $t$ testi uygulanmıştır. Buna yönelik sonuçlar aşağıdadır. 
Tablo 13. Üçüncü Derece Akrabası Girişimci Olanlar ile Olmayanların Girişimcilik Niyeti Açısından Farklılıklar (T Testi)

\begin{tabular}{|l|c|c|c|c|c|c|c|}
\hline \multirow{2}{*}{ Değişken } & \multicolumn{2}{|c|}{ Levene's Testi } & \multicolumn{3}{c|}{ T Testi } & \multicolumn{2}{c|}{ Aile (Ortalama) } \\
\cline { 2 - 8 } & $\mathrm{F}$ & Sig. & $\mathrm{t}$ & $\mathrm{df}$ & $\begin{array}{c}\text { Sig. (2- } \\
\text { tailed) }\end{array}$ & Olan & Olmayan \\
\hline Girişimcilik Niyeti & $\mathbf{, 0 0 0}$ & $\mathbf{, 9 8 7}$ & $\mathbf{, 7 5 1}$ & $\mathbf{2 4 4}$ & $\mathbf{4 5 3}$ & $\mathbf{2 , 7 9 5}$ & $\mathbf{2 , 6 7 9}$ \\
\hline
\end{tabular}

Anlamlı bir farklılık yoktur. Buna göre, hipotez 8 reddedilmiştir.

\section{Korelasyon Analizleri}

Korelasyon tablosu incelendiğinde, değişkenler arasında yüksek korelasyon olmadığ görülmüştür. Yüksek düzeyde ilişkiden söz etmek için korelasyon katsayısının 0,70'in üstünde olması gerekir. Korelasyon analizlerine yönelik sonuçlar aşağıdadır.

Tablo 14. Korelasyon Tablosu

\begin{tabular}{|l|r|r|}
\hline & & \\
Değişkenler & Girişimcilik Niyeti & \multicolumn{2}{|c|}{ Yenilikçi Davranış } \\
\hline Girişimcilik Niyeti & 1 & \multicolumn{2}{|c|}{, $287^{* *}$} \\
\hline Yenilikçi Davranış &, $287^{* *}$ & 1 \\
\hline
\end{tabular}

** Korelasyonlar 0.01 düzeyinde anlamlıdır.

Pearson Correlation kullanılmıştır.

\section{Etki Analizleri}

Etki analizleri AMOS yapısal eşitlik programı kullanılarak yapılmıştır. Bireyin sahip olduğu yenilikçilik düzeyinin girişimciliği etkileyeceği literatürde ele alınan bir konudur. Bu nedenle de yenilikçi davranışların girişimcilik niyetini etkileyeceği varsayılmaktadır. Bu varsayıma göre; 14 . Yenilikçi davranışlar girişimcilik niyetini anlamlı ve pozitif bir şekilde etkiler.

\section{Analiz Sonuçları}

Tablo 15 incelendiğinde; yenilikçi davranışların girişimcilik niyeti üzerinde anlamlı ve pozitif etkiye sahip olduğu görülmüştür. Model uyum değerleri kabul edilebilir seviyededir. Bu kapsamda, hipotez 14 kabul edilmiştir. Yapılan analizin sonuçları aşağıda sunulmuştur.

Tablo 15. Model Analiz Sonuçları

\begin{tabular}{|c|c|c|c|c|c|}
\hline \multicolumn{3}{|l|}{ Değişkenler } & \multirow{2}{*}{$\begin{array}{c}\text { Std. } \\
\text { Regresyon } \\
\text { Katsay1s1 } \\
, 207\end{array}$} & \multirow{2}{*}{\begin{tabular}{|c|} 
Anlamlılık \\
0,001
\end{tabular}} & \multirow{2}{*}{$\begin{array}{c}\mathrm{R}^{2} \\
0,117\end{array}$} \\
\hline $\begin{array}{l}\text { Girişimcilik } \\
\text { Niyeti }\end{array}$ & $<--$ & $\begin{array}{l}\text { Yenilikçi } \\
\text { Davranış }\end{array}$ & & & \\
\hline
\end{tabular}




\section{SONUÇ ve ÖNERILER}

Örgütteki çalışanların yenilikçi davranışlarını artırmak için bunları etkileyen faktörlerin bilinmesi gerekir (Damanpour, 1991). Bu anlamda yapılacak çalışmalardan biri de kamu ve özel sektörde çalışanların yenilikçi davranış algılarını belirlemek ve bu algı ile ilişkili olabileceği düşünülen kavramları test etmektir.

Alan yazındaki bazı araştırmalarda (Kristiansen ve Indarti, 2004; Liñán ve Chen, 2009; Göksel ve Aydıntan, 2011) demografik özellikler ile kişilik özellikleri bireylerin girişimcilik niyetlerini etkileyen önemli faktör olarak görülmektedir. Bu nedenle, araştırmada girişimcilik niyetine etkisinin olduğu düşünülen girişimci kişilik özelliklerinden olan yenilikçi davranış faktörü demografik özelliklerle birlikte ele alınıp incelenirken aynı zamanda aile geçmişinin etkileri de dikkate alınarak analizler yapılmıştır. Araştırmanın problem cümleleri şu şekilde oluşturulmuştur:

"Kamu ve özel sektörde çalışanların girişimcilik niyeti tutumunda kurumda çalışanların göstermiş oldukları yenilikçi davranışlar nelerdir?", "Aile geçmişinin kamu ve özel sektörde çalışanların göstermiş oldukları yenilikçi davranışlar ile girişimcilik niyeti tutumları üzerindeki etkileri nelerdir?".

Bu bağlamda, araştırmanın temel amacı; kamu ve özel sektörde çalışanların göstermiş oldukları yenilikçi davranışlar ile girişimcilik niyeti tutumlarının demografik özellikler açısından incelenmesinde aile geçmişinin etkilerini araştırmaktır. Bu temel amaç doğrultusunda aşağıdaki alt amaçlar belirlenmiştir:

1. Kamu ve özel sektörde çalışanların girişimcilik niyeti demografik özelliklerine göre farklılık göstermekte midir?

2. Kamu ve özel sektörde çalışanların yenilikçi davranışları demografik özelliklerine göre farklılık göstermekte midir?

3. Ebeveynleri girişimci olan bireyler ile ebeveynleri girişimci olmayan bireyler arasında girişimcilik niyeti açısından farklılık var mıdır?

4. Kamu ve özel sektörde çalışanların yenilikçi davranışları ile girişimcilik niyeti arasında ilişki var midır?

Bu araştırma sonucunda kamu ve özel sektörde çalışanların yenilikçi davranışlarını çalışma arkadaşlarının gözünden yorumlamak ve dolayısıyla örgütsel anlamda fikir edinebilmek amaçlanmaktadır.

Doğrulayıcı faktör analizi (DFA) iki aşamada gerçekleştirilmiştir. Yapılan ilk analizde bazı model uyum değerleri kabul edilebilir seviyenin altında ve bazı ifadelerin faktör yükleri 0,50'nin altında çıkmıştır. Bu nedenle, DFA modelinde bazı düzeltmeler yapılmıştır. İlk analiz sonucunda; girişimcilik niyeti 1 ve girişimcilik niyeti 2; yenilikçi davranış 1 ve yenilikçi davranış 3; yenilikçi davranış 4 ve yenilikçi davranış 5; yenilikçi davranış 6 ve yenilikçi davranış 7 nolu ifadeler birleştirilmiştir. Düşük faktör yükü nedeniyle yenilikçi davranış 2 nolu ifade analizden çıarılmıştır. Yapılan analizler sonucunda, faktör yükleri 0,50'nin üstündedir. Her faktör yükünün anlamlılık düzeyleri 0,001 olarak tespit edilmiştir.

Bireyin sahip olduğu yenilikçilik düzeyinin girişimciliği etkileyeceği literatürde ele alınan bir konudur. $\mathrm{Bu}$ nedenle de yenilikçi davranışların girişimcilik niyetini etkileyeceği varsayılmaktadır. Bu varsayıma göre; 14. Yenilikçi davranışlar girişimcilik niyetini anlamlı ve pozitif bir şekilde etkiler. Şeklinde hipotez oluşturulmuştur. 
Yapılan analizler sonucunda; yenilikçi davranışların girişimcilik niyeti üzerinde anlamlı ve pozitif etkiye sahip olduğu görülmüştür. Model uyum değerleri kabul edilebilir seviyededir. Bu kapsamda, hipotez 14 kabul edilmiştir. Girişimcilik niyeti açısından birinci derece ailesinde girişimci olanlar ile olmayanlar arasında anlamlı farklılık tespit edilmiştir. Birinci derece ailesinde girişimci olanların ortalaması daha yüksektir. Bu kapsamda, hipotez 6 kabul edilmiştir. Girişimcilik niyeti açısından ikinci derece ailesinde girişimci olanlar ile olmayanlar arasında anlamlı farklılık vardır. İkinci derece ailesinde girişimci olanların ortalamaları daha yüksektir. Bu bağlamda, hipotez 7 kabul edilmiştir. Girişimcilik niyeti açısından üçüncü derece ailesinde girişimci olanlar ile olmayanlar arasında ise anlamlı bir farklılık yoktur. Buna göre, hipotez 8 reddedilmiştir. Ancak Göksel ve Aydıntan (2011) çalışmasında ise ebeveynleri girişimci olan bireylerin, ebeveynleri girişimci olmayanlardan daha yüksek girişimci niyetlerine sahip olmayacağı sonucuna ulaşılmıştır. Elde ettiğimiz sonuçlar literatürdeki çalışmalardan farklılık göstermektedir. Bu tarz farklı sonuçların olması, bu alanda yapılan çalışmaların azlığı, farklı zaman dilimlerinde gerçekleştirilmiş olmaları ve ulaşılan kişilerden kaynaklanabilecek farklılıklardan dolayı doğaldır. Bu alanda yapılacak çalışmaların fazlalaşması ile birlikte genelleştirme yapılabilecek nitelikte bilgi oluşması muhtemeldir. Ayrıca bu bulgu literatürde devam eden tartışmalara da bir katkı sunmaktadır.

Yenilikçi davranışların ve girişimcilik niyetinin kişisel ve demografik özelliklerle arasındaki ilişkilerin ve bu özelliklerin kişilerin yenilikçi davranışlarını ve girişimcilik niyetlerini nasıl etkilediği konusunda aile geçmişinin etkilerinin araştırılması kurumların gelişimi ve girişim sayısının artması bakımından önemlidir.

Kamu sektöründe çalışanların yenilikçi fikirler öne sürmeye ne ölçüde açık oldukları ve girişimcilik niyetleri araştırılmalıdır. Yeniliğin giderek önem kazandığı günümüzde kurumların ve çalışanların da yenilikçi bir anlayışa sahip olmaları ve toplumun bu yöndeki beklentilerini karşılamaları gerekmektedir. Bu anlamda çalışanların yenilikçi davranışları benimsemesi ve bu çerçevede kendilerini geliştirmeleri önemlidir. Ancak bunun için atılacak adımlarda ilk olarak çalışanların yenilikçi davranışları ne ölçüde gösterdiklerini belirlemek araştırmacılara ve uygulayıcılara geliştirilecek programlar konusunda yol gösterici olacaktır. Bu anlamdaki eksikliği gidereceği düşünülmektedir.

Çalışmamıza Ankara ve İstanbul İllerindeki kamu ve özel sektörde faaliyet gösteren kurum ve kuruluşlarda çalışan personelin katılmış olması çalışmanın en önemli kısıtlılığını oluşturmaktadır. Benzer çalışmayı yapacak araştırmacıların bölgesel, meslek grubu veya sektörel farklılıkları da dikkate alacak şekilde geniş bir örneklem üzerinde araştırma çalışması yapması önerilmektedir.

\section{KAYNAKÇA}

Ajzen, I. (1991). The Theory of Planned Behavior, Organizational and Human Decision Processes, 50: 179-211.

Amabile, T. M. (1988). A Model of Creativity and Innovation in Organizations, Research in Organizational Behaviour, 10: 123-167.

Autio, E., Keeley, R. H., Klofsten, M., Parker, G. G. C. and Hay, M. (2001). Entrepreneurial intent among students in Scandinavia and in the USA, Enterprise and Innovation Management Studies, 2(2): 145-160.

Bandura, A. (1986). The Social Foundations of Thought and Action. Englewood Cliffs, NJ: Prentice Hall. 
Bateman, T. S. and Crant, J. M. (1993). The Proactive Component of Organizational Behavior: A Measure and Correlates, Journal of Organizational Behavior, 14(2): 103-118.

Bayram, N. (2010). Yapısal Eşitlik Modellemesine Giriş: Amos Uygulamaları. Bursa: Ezgi Kitabevi.

Bird. B. (1988). Implementing Entrepreneurial Ideas: The Case for Intentions, Academy of Management Review, 13(3): 442-453.

Bozkurt, Ö. Ç., Kalkan, A., Koyuncu, O. ve Alparslan, A. M. (2012). Türkiye'de Girişimciliğin Gelişimi: Girişimciler Üzerinde Nitel Bir Araştırma, Süleyman Demirel Üniversitesi Sosyal Bilimler Enstitüsü Dergisi, 1(15): 229-247.

Brockhaus, R. H. (1982). The Psychology of The Entrepreneur, Encyclopedia of Entrepreneurship. Ed.: C. A. Kent, D. L. Sexton and K. H. Vesper. Englewood Cliffs, NJ: Prentice Hall.

Carland. J. W., Carland, J. A. C., Hoy, F. and Boulton. W. (1984). Differentiating Entrepreneurs from Small Business Owners: A Conceptualization, Academy of Management Review, 9(2): 354-359.

Carland. J. W., Carland, J. A. C., Hoy, F. and Boulton. W. (1988). Distinctions Between Entrepreneurial and Small Business Ventures: An Empirical Investigation, International Journal of Management, 50: 98-103.

Chandler, G. N. and Lyon, D. W. (2001). Issues of Research Design and Construct Measurement in Entrepreneurship Research: The Past Decade, Entrepreneurship Theory and Practice, 25(4): 101113.

Chen, C. C., Greene, P. G. and Crick, A. (1998). Does Entrepreneurial Self-Efficacy Distinguish Entrepreneurs From Managers?, Journal of Business Venturing, 13(4): 295-316.

Collins, O. F. and Moore, D. G. (1970). The Organization Makers. New York: Appleton-CenturyCrofts.

Coulter, M. (2003). Entrepreneurship in Action. Second Ed., Upper Saddle River, NJ: Prentice Hall.

Çimen, İ. ve Yücel, C. (2017). Yenilikçi Davranış Ölçeği (YDÖ): Türk Kültürüne Uyarlama Çalışması, Cumhuriyet International Journal of Education - Cumhuriyet Uluslararası Eğitim Dergisi, 6(3): 365-381.

Damanpour, F. (1991). Organizational Innovation: A Meta-Analysis of Effects of Determinants and Moderators, The Academy of Management Journal, 34(3): 555-590.

De Jong, J. and Den Hartog, D. N. (2010). Measuring Innovative Work Behaviour, Creativity and Innovation Management, 19(1): 23-35.

Dyer, J. H., Gregersen, H. B. and Christensen, C. M. (2011). The Innovator's DNA: Mastering the Five Skills of Disruptive Innovators. Boston, MA: Harvard Business Press.

Ercan, S. ve Gökdeniz, İ. (2009). Girişimciliğin Gelişim Süreci ve Girişimcilik Açısından Kazakistan, Bilig Türk Dünyası Sosyal Bilimler Dergisi, 49: 59-82.

Erikson, T. (1999). A Study of Entrepreneurial Career Choices Among Mbas - The Extended Bird Model, Journal of Enterprising Culture, 7(1): 1-17.

Fayolle, A., Gailly, B. and Lassas-Clerc, N. (2006). Assessing the Impact of Entrepreneurship Education Programmes: A New Methodology, Journal of European Industrial Training, 30(9): 701720.

Gomolka, E. (1977). Characteristics of Minority Entrepreneurs and Small Business Enterprises, American Journal of Small Business, 2(1): 12-21. 
Goswami, S. and Mathew, M. (2005). Definition of Innovation Revisited: An Empirical Study on Indian Information Technology Industry, International Journal of Innovation Management, 9(3): 371383.

Göksel, A. and Aydıntan, B. (2011). Gender, Business Education, Family Background and Personal Traits; a Multi-Dimensional Analysis of Their Affects on Entrepreneurial Propensity: Findings from Turkey, International Journal of Business and Social Science, 2(13): 35-48.

Greenspoon, P. and Saklofske, E. (1998). Confirmatory factor analysis of the multidimensional Student's Life Satisfaction Scale, Personality and Individual Differences, 25(5): 965-971.

Hair, J. F., Black, W. C., Babin, B. J. and Anderson, R. E. (2010). Multivariate Data Analysis: A Global Perspective. 7th Ed., Upper Saddle River, NJ: Pearson.

Hisrich, R. D. (1986). The Woman Entrepreneur: Characteristics, Skills, Problems and Prescriptions for Success, Art and Science of Entrepreneurship. Ed.: D. L. Sexton and R. W. Smilor, Cambridge, MA: Ballinger, 61-81.

İşcan, F. ve Kaygın, E. (2011). Potansiyel Girişimciler Olarak Üniversite Öğrencilerinin Girişimcilik Eğilimlerini Belirlemeye Yönelik Bir Araştırma, Organizasyon ve Yönetim Bilimleri Dergisi, 3(2): 275-286.

Janssen, O. (2000). Job Demands, Perceptions of Effort-Reward Fairness, and Innovative Work Behavior, Journal of Occupational and Organizational Psychology, 73(3): 287-302.

Kickul, J. and Zaper, J. A. (2000). Untying the knot: do personal and organizational determinants influence entrepreneurial intentions?, Journal of Small Business and Entrepreneurship, 15(3): 57-77.

Kolvereid, L. (1996). Prediction of employment status choice intentions, Entrepreneurship Theory and Practice, 21(1): 47-57.

Kolvereid, L. and Isaksen, E. (2006). New business start-up and subsequent entry into selfemployment, Journal of Business Venturing, 21(6): 866-885.

Korkmaz, O. (2012). Üniversite Öğrencilerinin Girişimcilik Eğilimlerini Belirlemeye Yönelik Bir Araştırma: Bülent Ecevit Üniversitesi Örneği, Afyon Kocatepe Üniversitesi İ̈BF Dergisi, 14(2): 209226.

Kristiansen, S. and Indarti, N. (2004) Entrepreneurial Intention Among Indonesian and Norwegian Students, Journal of Enterprising Culture, 12(1): 55-78.

Krueger, N. F. (1993). The impact of prior entrepreneurial exposure on perceptions of new venture feasibility and desirability, Entrepreneurship Theory and Practice, 18(1): 5-21.

Krueger, N. F. and Brazeal, D. V. (1994). Entrepreneurial Potential and Potential Entrepreneurs, Entrepreneurship Theory and Practice, 19(3): 91-104.

Krueger, N. F., Reilly, M. D. and Carsrud, A. L. (2000). Competing models of entrepreneurial intentions, Journal of Business Venturing, 15(5-6): 411-432.

Langer, E. (1983). The Psychology of Control. Beverly Hills: Sage Publications.

Lee, S. H. and Wong, P. K. (2004). An exploratory study of technopreneurial intentions: a career anchor perspective, Journal of Business Venturing, 19(1): 7-28.

Lewin, K. (1951). Field Theory in Social Science. New York: Harper and Row.

Liles, P. (1974). Who Are the Entrepreneurs, MSU Business Topics, 22, 5-14. 
Liñán, F. and Chen, Y.-W. (2009). Development and Cross-Cultural Application of a Specific Instrument to Measure Entrepreneurial Intentions, Entrepreneurship Theory and Practice, 33(3): 593617.

McClelland, D. (1961). The Achieving Society. NJ: Princeton.

Mumford, M. D. (2003). Where Have We Been, Where Are We Going? Taking Stock in Creativity Research, Creativity Research Journal, 15(2-3): 107-120.

Ören, K. ve Biçkes, M. (2011). Kişilik Özelliklerinin Girişimcilik Potansiyeli Üzerindeki Etkileri (Nevşehir'deki Yüksek Öğrenim Öğrencileri Üzerine Yapılan Bir Araştırma), Süleyman Demirel Üniversitesi İktisadi ve İdari Bilimler Fakültesi Dergisi, 16(3): 67-86.

Perry, C. (1990). After Further Sightings of The Heffalump, Journal of Managerial Psychology, 5(2): 22-31.

Peterman, N. E. and Kennedy, J. (2003). Enterprise education: Influencing students' perceptions of entrepreneurship, Entrepreneurship-Theory and Practice, 28(2): 129-144.

Read, A. (2000). Determinants of Successful Organisational Innovation: A Review of Current Research, Journal of Management Practice, 3(1): 95-119.

Reitan, B. (1998). Perspectives on new venture creation. The stimulation of entrepreneurial potential and new venture attempts among young people, Unpublished Doctoral Dissertation, The Norwegian University of Science and Technology, Department of Social Sciences and Technology Management, Trondheim, Norway.

Reuvers, M., van Engen, M. L., Vinkenburg, C. J. and Wilson-Evered, E. (2008). Transformational Leadership and Innovative Work Behavior: Exploring the Relevance of Gender Differences, Creativity and Innovation Management, 17(3): 227-244.

Scott, S. G. and Bruce, R. A. (1994). Determinants of Innovative Behavior: A Path Model of Individual Innovation in the Workplace, The Academy of Management Journal, 37(3): 580-607.

Scott, S. G. and Bruce, R. A. (1998). Following the Leader in R\&D: The Joint Effect of Subordinate Problem-Solving Style and Leader-Member Relations on Innovative Behavior, IEEE Transactions on Engineering Management, 45(1): 3-10.

Senge, P. (2000). Beşinci Disiplin. Çev.: A. İldeniz ve A. Doğukan, İstanbul: YKY.

Shane, S. and Venkataraman, S. (2000). The Promise of Entrepreneurship as a Field of Research, The Academy of Management Review, 25(1): 217-226.

Shapero, A. (1975). The Displaced, Uncomfortable Entrepreneur, Psychology Today, 9(6): 83-88.

Shapero, A. (1982). Social Dimensions of Entrepreneurship, Encyclopedia of Entrepreneurship. Ed.: C. Kent, D. Sexton and K. Vesper, Englewood Cliffs, NY: Prentice Hall, 72-90.

Stevenson. H., Roberts, M. and Grousbeck, H. (1989). New Business Ventures and The Entrepreneur. Boston: Irwin.

Şeşen, H. ve Basım, N. (2012). Demografik Faktörler ve Kişiliğin Girişimcilik Niyetine Etkisi: Spor Bilimleri Alanında Öğrenim Gören Üniversite Öğrencileri Üzerine Bir Araştırma, Ege Akademik Bakış, 12(Özel Sayı): 21-28.

Thorne, J. R. and Ball, J. G. (1981). Entrepreneurs and Their Companies, Frontiers of Entrepreneurship Research: The Proceedings of The Babson Conference on Entrepreneurship Research. Ed.: K. H. Vesper, Wellesley, Mass.: Babson College, 65-83. 
Thurlings, M., Evers, A. T. and Vermeulen, M. (2015). Toward a Model of Explaining Teachers' Innovative Behavior: A Literature Review, Review of Educational Research, 85(3): 430-471.

Tikici, M. ve Aksoy, A. (2009). Girişimcilik ve Küçük İşletmeler. Ankara: Nobel.

Tkachev, A. and Kolvereid, L. (1999). Self-employment intentions among Russian students, Entrepreneurship and Regional Development, 11(3): 269-280.

Uslu, D. (2015). Bilgisayar ve Öğretim Teknolojileri Eğitimi Bölümü Öğrencilerinin Girişimci Kişilik Özellikleri ve Girişimcilik Niyetinin Duygusal Zekâ Faktörlerine Göre İncelenmesi, Yayımlanmamış Doktora Tezi, Gazi Üniversitesi Eğitim Bilimleri Enstitüsü, Ankara.

Van de Ven, A. (1986). Central Problems in the Management of Innovation, Management Science, 32(5): 513-644.

Veciana, J. M., Aponte, M. and Urbano, D. (2005). University students' attitudes towards entrepreneurship: a two countries comparison, International Entrepreneurship and Management Journal, 1(2): 165-182.

Vesper, K. H. (1980). New Venture Strategies. Englewood Cliffs, NJ: Prentice-Hall.

White, R. W. (1959). Motivation Reconsidered: The Concept of Competence, Psychological Review, 66: 297-333.

Yılmaz, A. S. (2014). Bir Değişim Ajanı Olarak Girişimcilik Eğitimi, Zeitschrift für die Welt der Türken - Journal of World of Turks, 6(1): 297-310.

Zhao, H., Hills, G. E. and Siebert, S. E. (2005). The mediating role of self-efficacy in the development of entrepreneurial intentions, Journal of Applied Psychology, 90(6): 1265-1272. 